\title{
Estágio probatório no Sul do Brasil: uma comparação de práticas utilizadas na esfera municipal
}

\author{
Vanessa B. Nachtigall \\ Especialista em Gestão Pública, Porto Alegre, RS, Brasil

\section{Paola Carmen Valenzuela Cánepa} \\ Universidade Estadual do Rio Grande do Sul (UERGS), Porto Alegre, RS, Brasil
}

\section{Resumo}

O estágio probatório constitui uma etapa necessária para a aquisição da estabilidade no serviço público. Avalia o desempenho do servidor estatutário, visando manter no setor público apenas aqueles que apresentam determinado nível de desempenho. O presente estudo analisa o estágio probatório das três capitais da Região Sul do Brasil (Curitiba, Florianópolis e Porto Alegre) com o intuito de verificar possíveis semelhanças e particularidades entre os municípios, além da adequação de sua implementação à Constituição Federal e à literatura na área. Para tal, analisouse a legislação que regulamenta o estágio probatório em cada município, caracterizando-se como um estudo de casos múltiplos. Os resultados deste estudo não apontaram diferenças marcantes no processo de estágio probatório nas capitais investigadas, identificando-se pequenas particularidades nos fatores analisados. Verificaram-se ainda fragilidades quanto à abrangência dos requisitos de avaliação e quanto à qualificação dos avaliadores para o desempenho dessa função.

Palavras-chave: avaliação especial de desempenho, estágio probatório, avaliação de desempenho 


\section{Evaluación de la etapa probatoria en el Sur de Brasil: una comparación de las prácticas utilizadas en el ámbito municipal}

La etapa probatoria constituye un periodo necesario para la adquisición de la estabilidad en el sector público brasilero. Evalúa el desempeño del funcionario estatutario, visando mantener en el sector apenas aquellos que presentan un determinado nivel de desempeño. El presente estudio analiza la etapa probatoria de las tres capitales de la Región Sur de Brasil (Curitiba, Florianópolis y Porto Alegre) con el propósito de verificar posibles semejanzas y particularidades a los entes federados, así como su adecuación a la Constitución Federal y la literatura en el área. Para esto, se analizó a legislación que regula la etapa probatoria en cada municipio, caracterizándose como un estudio de caso múltiple. Los resultados de este estudio no señalaran diferencias resaltantes en el proceso de etapa probatoria en los municipios investigados, se identificó pequeñas particularidades en los factores analizados. Se verificó fragilidades referentes a la cobertura de los requisitos de evaluación y referentes a la cualificación de los evaluadores para el desempeño de esta función.

Palabras clave: evaluación especial de desempeño, etapa probatoria, evaluación del desempeño

\section{Probation period in Southern Brazil: a comparison of municipal practices}

The probation period is a necessary stage for acquiring tenure in the Brazilian public sector. Its purpose is to evaluate the new statutory employee in the position in charge, in order to keep only the ones who present a set level performance. This study approaches the probation period in three capitals of Southern Brazil (Curitiba, Florianópolis and Porto Alegre) looking for possible similarities and characteristics, and adequacy of its implementation to the Federal Constitution and literature in the area. For such, the legislation that regulates the probation period in each city was analyzed in this multiple case study. The results of this study do not point out critical differences in the probation period process of the target cities, identifying only small specific characteristics in the assessed factors. Some weaknesses were found: the scope of the evaluation requirements and the qualification of the evaluators that develops such activity.

Keywords: special performance evaluation, probation period, performance measurement 


\section{Introdução}

A perspectiva de estabilidade no emprego motiva muitas pessoas a buscar uma vaga no setor público. O concurso para um cargo de provimento efetivo constitui um primeiro passo nesse sentido. No entanto, a sonhada estabilidade só será alcançada após a aprovação na avaliação especial de desempenho realizada ao longo do estágio probatório.

O estágio probatório tem como objetivo avaliar o desempenho do servidor na execução das atribuições do cargo para o qual prestou concurso. Ele reveste-se, assim, de elevada importância seja para o servidor, seja para o serviço público. Para o primeiro, o estágio probatório representa a possibilidade de adquirir a estabilidade em um cargo público. Para o segundo, representa a oportunidade de manter em seu quadro funcional permanente apenas os servidores que demonstraram determinado nível de desempenho.

A avaliação de estágio probatório é apontada, assim, como uma etapa complementar ao processo seletivo de servidores públicos (AMORIM; LUZ; SILVA, 2011). No entanto, alguns estudos questionam sua efetividade para dispensar servidores que apresentam baixo desempenho, identificando-a como apenas uma formalidade administrativa em muitos contextos (ALVES, 2014; FicAgna et al., 2014).

O estágio probatório já estava presente na Constituição Federal de 1988. Contudo, a Emenda Constitucional no 19, de 1998, traz a ela mudanças substanciais: amplia seu período de duração e impõe a efetiva realização da avaliação de desempenho para a aquisição da estabilidade, findando com a possibilidade de mero decurso de prazo para esse fim.

Embora o texto constitucional estabeleça os parâmetros básicos para a referida avaliação, ele permite que cada ente federativo defina aspectos relevantes desse processo de acordo com suas características específicas. Tal aspecto se reflete nos entes de todas as esferas de governo e em seus diferentes poderes. Contudo, o Executivo municipal constitui a esfera de governo mais próxima à população (LISBOA; SANTIAGO; JUNIOR, 2016) em função da gama de serviços pela qual é responsável. Mostra-se plausível, então, que essa esfera de governo demande uma maior adaptação dos procedimentos de estágio probatório para adequá-lo a suas especificidades. 
Assim, este estudo buscou analisar o estágio probatório das capitais da Região Sul do Brasil, verificando possíveis semelhanças e particularidades na legislação das três capitais, assim como o alinhamento da prática municipal com os pressupostos constitucionais e com a literatura da área. Tal análise comparativa justifica-se por possibilitar a identificação das práticas implementadas pelos referidos municípios quanto à avaliação de estágio probatório, permitindo verificar se eles estão alinhados às normas gerais que regem todos os entes federados e se utilizam, de forma efetiva, a autonomia que a Constituição Federal Ihes concede para adequar sua legislação a suas particularidades.

\section{Avaliação especial de desempenho}

A Constituição Federal de 1988 estabeleceu, em sua redação original, a obrigatoriedade do cumprimento do estágio probatório ${ }^{1}$ aos servidores públicos efetivos. O texto legal, no entanto, vinculava a estabilidade no serviço público ao transcorrer do período de dois anos de exercício. Tal aspecto permitia, na prática, que servidores fossem confirmados no serviço público mesmo sem ter seu desempenho avaliado, seja por ineficiência da administração para realizar a avaliação, seja por afastamentos legais do próprio servidor. A emenda constitucional de 1998, no entanto, modificou essa situação:

Art. 41. São estáveis após três anos de efetivo exercício os servidores nomeados para cargo de provimento efetivo em virtude de concurso público. (Redação dada pela Emenda Constitucional no 19, de 1998)

$[\ldots]$

$\S 4$ 으 Como condição para a aquisição da estabilidade, é obrigatória a avaliação especial de desempenho por comissão instituída para essa finalidade. (Incluído pela Emenda Constitucional no 19, de 1998) (BRASIL, 1998, s/p)

Assim, se, antes de 1998, o simples decorrer de dois anos de exercício possibilitava o alcance da estabilidade ao servidor nomeado para cargo de provimento efetivo em virtude de concurso público, a partir da Emenda no 19/1998, dois requisitos passaram a ser exigidos: o decurso de três anos de efetivo exercício e a aprovação em avaliação de desempenho a ser realizada por comissão instituída para esta finalidade (MODESTO, 2002).

\footnotetext{
${ }^{1}$ São submetidos ao estágio probatório somente os servidores estatutários.
} 
No entanto, verifica-se que, mesmo após a publicação da referida emenda, o texto constitucional estabelece apenas linhas gerais para a implementação do estágio probatório em âmbito nacional. Deixa, dessa forma, um espaço significativo para que cada ente federativo defina, em lei própria, aspectos essenciais à avaliação de desempenho de seus servidores, considerando seu contexto específico. Entre os procedimentos do processo avaliativo regulamentados pela legislação municipal, estão, por exemplo: os requisitos de avaliação, a definição de critérios para estabilidade, exoneração ou suspensão do estágio probatório, a composição dos avaliadores e as ações de desenvolvimento vinculadas à avaliação (MODESTo, 2002; Alves, 2014; ReYNAUd, 2016).

Os requisitos de avaliação definem os aspectos do desempenho do servidor que serão considerados para fins de avaliação. Para serem efetivos, é necessário que sejam descritos de forma clara, possibilitando que os diferentes indivíduos tenham um entendimento similar desses requisitos, bem como que eles sejam adequados ao que se espera de cada cargo no contexto da organização em que são implementados.

A definição quanto aos indivíduos responsáveis pela realização da avaliação também constitui um aspecto-chave para que o resultado desta represente, de fato, o desempenho do servidor. Os avaliadores têm a responsabilidade de transpor para o instrumento de avaliação o efetivo desempenho do servidor, bem como de assinalar os aspectos de sua atuação que devem ser revistos. Dessa forma, mostra-se relevante que as organizações qualifiquem os avaliadores de estágio probatório para o exercício de tal função, dando especial atenção à condução de um feedback que auxilie o servidor a potencializar seu desempenho.

A Constituição ainda permite que as organizações definam os critérios para aquisição de estabilidade e exoneração dos seus servidores. Os entes federativos podem, assim, estabelecer, em sua legislação própria, o que esperam como desempenho mínimo de seus servidores para que estes se tornem estáveis, além de outros elementos que considerem relevantes.

O texto consitucional ainda aponta que a avaliação deve considerar o efetivo exercício do servidor, podendo cada orgão disciplinar o tempo de afastamento de tal exercício a partir do qual o período de avaliação fica prejudicado e exigir, a partir de então, uma ampliação 
do prazo para que a avaliação possa ser realizada. Em um país de dimensões continentais e características tão distintas em suas diferentes regiões, a possibilidade de definição local dos fatores que caracterizam o estágio probatório permite a este instrumento melhores condições de responder às reais necessidades de cada ente público.

\section{Modelo burocrático X Modelo gerencial}

A Emenda Constitucional no 19/1998 foi fortemente marcada pelo Plano Diretor da Reforma do Aparelho do Estado (PDRAE), o qual propunha a implementação da administração gerencial no serviço público brasileiro. A administração gerencial foi apresentada, pelo referido plano, como um avanço em relação ao modelo burocrático, este apontado como excessivamente formalista, autocentrado e ineficiente. $\mathrm{O}$ modelo burocrático seria assim incapaz de responder às dinâmicas necessidades da população. A administração gerencial, por outro lado, promoveria uma maior flexibilidade na gestão de pessoas e maior eficiência na prestação de serviços com foco nos resultados a serem obtidos e não mais nos processos de trabalho como o modelo anterior (BRASIL, 1995).

Alinhada a esses objetivos, a Emenda Constitucional nำ 19/1998 instituiu a eficiência como princípio à administração pública e estabeleceu novas figuras institucionais, como os contratos de gestão (art. 37, § 8으, inciso II), entre outras mudanças (SUzUKI; GABBI, 2009). Os referidos contratos de gestão mostram-se ilustrativos de aspectos do modelo de administração pública gerencial: contratação de objetivos precisos a serem alcançados, ampliação da autonomia na gestão dos recursos humanos, materiais e financeiros disponíveis e cobrança dos resultados alcançados.

A Emenda Constitucional no 19/1998 deu assim passos importantes na direção de uma administração gerencial, mas sem substituir de todo o modelo burocrático. Verificamse ainda hoje os dois modelos atuando concomitantemente na gestão pública nacional, por vezes pendendo mais para um lado, por vezes mais para outro.

O estágio probatório não se mostra imune a essa dicotomia. Considerando que as instituições públicas se pautam por ambos os modelos, a avaliação de seus novos 
membros também está sujeita à referida dicotomia. Nesse sentido, ao considerar os requisitos da avaliação de estágio probatório do Governo Federal, estabelecidos pela Lei no 8.112/1990, por exemplo, verifica-se a emergência de fatores como capacidade de iniciativa, produtividade e responsabilidade, alinhados ao modelo gerencial, ao mesmo tempo que a referida lei manteve os fatores assiduidade e disciplina já constantes na legislação anterior (Lei no 1.711/1952), mais alinhados ao modelo burocrático.

\section{Estágio probatório}

O estágio probatório tem como objetivo verificar se o servidor público possui as condições necessárias para o desempenho das atribuições do cargo para o qual prestou concurso público. Tem início com a entrada do servidor em efetivo exercício e finda com a aquisição de sua estabilidade ou com sua exoneração. É apontado então, por diferentes pesquisadores, como uma etapa complementar ao processo de seleção iniciado pelo concurso público (Alves, 2014; AMORIM; LUZ; SilvA, 2011; Bergue, 2007).

Os concursos públicos são constituídos, de forma geral, por certame de provas ou provas e títulos, com questões, com frequência, somente de múltipla escolha. O estágio probatório, nesse contexto, agrega elementos bastante distintos ao processo seletivo, uma vez que avalia o efetivo desempenho das atividades para as quais o servidor foi contratado no contexto específico do órgão no qual deverá executá-las. Pode-se questionar, contudo, se o estágio probatório consegue, de fato, cumprir essa função nos diferentes entes federativos nacionais.

Embora a literatura ainda careça de estudos que possibilitem estabelecer um panorama claro da realidade nacional, pesquisas na área já indicam uma série de dificuldades nesse sentido. Assim, estudos apontam que o estágio probatório não tem sido efetivo para dispensar servidores que apresentam baixo desempenho, sendo muitas vezes tratado apenas como uma formalidade administrativa (ALVES, 2014; FICAGNA et al., 2014).

Diferentes fatores contribuem para esses achados. Ficagna et al. (2014) apontam que alguns avaliadores não atribuem a nota adequada ao servidor durante as avaliações 
de estágio probatório para evitar conflitos com o servidor. Não se sentir capacitado para avaliar o desempenho do subordinado ou não identificar importância na avaliação também são fatores identificados que impactam diretamente os resultados obtidos nesse processo (FEITOSA; LIMA, 2016).

Sabe-se que a avaliação de desempenho não se constitui em uma tarefa de simples execução. Contudo, tais comportamentos, por parte dos avaliadores, comprometem o resultado das avaliações realizadas por eles e prejudicam a credibilidade do estágio probatório como um todo. Dessa forma, Modesto (2002) aponta que o desafio das organizações públicas hoje seria dar efetividade à exigência constitucional do estágio probatório como um processo administrativo capaz de identificar os servidores aptos ao desempenho das funções públicas ao mesmo tempo em que garanta os direitos subjetivos desses servidores.

\section{Para além da mensuração do desempenho}

Além de identificar os servidores com condições de se tornarem estáveis nas instituições públicas entre todos os que nelas ingressam, o estágio probatório também pode contribuir com o desenvolvimento profissional desses servidores. O adequado acompanhamento do servidor durante o estágio probatório permitiria aos entes federativos identificar continuamente de que forma está se dando a adaptação dos novos membros ao ambiente de trabalho, bem como quais são as principais dificuldades de desempenho enfrentadas por eles no dia a dia do trabalho (NETO; GOMES, 2003; GARCIA; LIMA; ASSUNÇÃO, 2010; ALVES, 2010).

A avaliação possibilita a comparação do desempenho do servidor ao desempenho esperado pela organização, assim como comparar o desempenho do próprio servidor ao longo de determinado período. Essas informações permitem à organização estruturar suas ações de capacitação e desenvolvimento de forma alinhada às reais necessidades de seu corpo funcional, potencializando assim seu impacto. Permitem ainda, dentro do possível, alocar seus servidores em atividades ou setores que possibilitem o melhor aproveitamento de seu desempenho. Infelizmente, Neves e Benito (2004) apontam que, muitas vezes, a 
avaliação de desempenho está desarticulada das demais práticas de gestão de pessoas nas organizações públicas, não sendo assim utilizada em todo seu potencial.

\section{Metodologia de pesquisa}

A presente pesquisa caracteriza-se como um estudo de casos múltiplos (YıN, 2001) e buscou investigar o estágio probatório das três capitais da Região Sul do Brasil. Inicialmente, os procedimentos adotados por cada município foram apresentados individualmente e, em um segundo momento, procedeu-se à análise temática comparando as capitais entre si e analisando-as com as diretrizes constantes na Constituição Federal e na literatura da área.

Para a coleta de dados, utilizou-se a análise documental (GIL, 2002). Foram pesquisadas as legislações municipais que regulamentam o estágio probatório em cada uma das capitais e seus instrumentos de avaliação. Utilizaram-se como categorias de análise: requisitos de avaliação, critérios para estabilidade, exoneração e suspensão do estágio probatório, critérios para a definição dos avaliadores, e a vinculação da referida avaliação com ações de desenvolvimento profissional. As categorias de análise foram estabelecidas pelas autoras, a partir da leitura preliminar das legislações municipais referentes ao estágio probatório, em função de sua relevância ao processo de avaliação e por consistirem em aspectos de competência de cada ente federal para sua regulamentação legal (CURITIBA, 2003, 2008, 2010; Florianópolis, 2003, 2016; Porto Alegre, 1985, 2009, 2011).

Para esta pesquisa, foram analisadas as cidades: Curitiba, Florianópolis e Porto Alegre. O estudo concentrou-se em uma única esfera de governo para possibilitar uma comparação mais uniforme entre os elementos analisados. Optou-se ainda pelos referidos municípios por constituírem as capitais de seus estados e, dessa forma, esperar-se que tivessem procedimentos relativos à avaliação de desempenho analisada já consolidados.

Curitiba, capital do Estado do Paraná, possui aproximadamente 30 mil servidores em seu quadro funcional (CURITIBA, 2018). O estágio probatório no município é regulamentado pelas Leis no 10.815/2003 e nำ12.814/2008 e pelo Decreto nㅇ530/2010. Florianópolis, capital 
do Estado de Santa Catarina, possui cerca de oito mil servidores em seu quadro funcional (FLORIANóPOLIS, 2018) e seu estágio probatório é regulamentado pela Lei no 63/2003 e pelo Decreto $n$ 오 16.550/2016 e suas alterações (Decretos no 16.925/2016 e no 17.937/2017). Já Porto Alegre, capital do Estado do Rio Grande do Sul, possui cerca de 15 mil servidores ativos em seu quadro funcional (PORTO ALEGRE, 2018) e tem seu estágio probatório regulamentado pelas Leis n으 133/1985 e no 701/2012 e Decretos nㅇ 16.256/2009, nㅇ 16.972/2011 e n은 19.513/2016. Porto Alegre possui uma legislação e respectivo instrumento de avaliação específicos para o cargo de Procurador Municipal; e outra legislação e instrumento para o restante dos cargos da instituição. Neste estudo, analisaremos apenas a legislação aplicada para a grande maioria dos cargos do município por considerar que é a mais representativa da avaliação realizada na instituição. O instrumento de avaliação das três capitais analisadas é um anexo das legislações que regram os respectivos estágios probatórios (CURITIBA, 2010; Florianópolis, 2016; PORTO Alegre, 2009).

Este estudo buscou, assim, analisar o estágio probatório das três capitais da Região Sul do Brasil, identificando possíveis semelhanças e particularidades entre os casos, bem como comparando suas práticas aos pressupostos constitucionais e à literatura da área. Mais especificamente, buscou analisar os requisitos de avaliação, os critérios para estabilidade, exoneração ou suspensão do estágio probatório e para a definição dos avaliadores, assim como a vinculação da referida avaliação com ações de desenvolvimento profissional.

\section{Estágio probatório nas capitais da região sul do Brasil}

\section{O Caso de Curitiba/PR}

As avaliações em Curitiba têm periodicidade semestral. São realizadas por uma comissão especial formada para esse fim, composta pela chefia imedita do servidor e dois servidores estáveis, juntamente com o servidor avaliado². Para alcançar a estabilidade, o servidor deve obter resultado de apto em sua avaliação, o que exige uma pontuação

\footnotetext{
${ }^{2}$ As comissões de avaliação de estágio probatório para avaliação de titulares do cargo de Guarda Municipal e de servidores em unidades escolares da Secretaria Municipal da Educação possuem composição especial: entre três e seis membros, sendo obrigatória a participação da chefia imediata na avaliação. No caso das unidades escolares, a comissão também deve ser composta por representantes dos diferentes segmentos do conselho de escola.
} 
igual ou superior a 75 pontos, bem como ser aprovado em todas as disciplinas do curso de formação profissional, nos cargos em que tal curso é exigido.

A legislação do município estabelece atividades e licenças que não são consideradas efetivo exercício para fins de estágio probatório. Dessa forma, durante o referido período, o servidor tem o estágio suspenso, havendo uma ampliação do prazo para obter a estabilidade.

O servidor poderá ser exonerado ao final do estágio caso não apresente a pontuação mínima exigida para estabilidade ou, mesmo antes de sua finalização, quando verificada infração disciplinar. Para os cargos em que há a exigência de curso de formação profissional, faltas ou baixa pontuação nesse também podem motivar a exoneração do servidor.

Em relação às ações de desenvolvimento profissional implementadas durante o estágio probatório, a legislação municipal determina a participação do servidor em capacitação sobre os critérios de estágio probatório, preferencialmente, em seu primeiro ano no município. Também estabelece o monitoramento, pela administração, dos resultados do sistema de avaliação especial de desempenho, de modo a contribuir para a capacitação dos servidores em estágio probatório, quando necessário.

O instrumento de avaliação utilizado é único para os diferentes cargos do município. O campo relativo aos requisitos de avaliação possui uma escala com três graduações para cada item, que deve ser preenchida com um número de um a 10. Pontuação de um a quatro pontos refere-se a um desempenho fraco; de cinco a sete, regular; e de oito a 10 , bom. Destaca-se ainda no instrumento a presença de campo específico intitulado Indicações sobre os procedimentos necessários para reduzir as dificuldades apontadas. A legislação municipal estabelece que a comissão avaliadora preencha esse campo, de forma objetiva, acerca dos requisitos em que o servidor obtiver desempenho regular ou fraco, permitindo que estes sejam acompanhados durante o período subsequente, bem como revistos na avaliação posterior. Esse ponto permite explicitar de forma particularizada os pontos a serem trabalhados por cada servidor para melhorar seu desempenho, facilitando seu monitoramento e reavaliação no período seguinte. $\mathrm{Na}$ Tabela 1, são apresentados os requisitos considerados no instrumento de avaliação e sua descrição feita na legislação pertinente. 
Tabela 1 |Requisitos de avaliação de estágio probatório de Curitiba

\begin{tabular}{|c|c|}
\hline Requisito & Descrição \\
\hline $\begin{array}{l}\text { Conhecimento para o } \\
\text { trabalho }\end{array}$ & $\begin{array}{l}\text { Aplicar conhecimentos técnicos e práticos pertinentes ao cargo na } \\
\text { execução das ações necessárias para atingir os objetivos da unidade de } \\
\text { trabalho do órgão de lotação }\end{array}$ \\
\hline Pontualidade & $\begin{array}{l}\text { Cumprir o horário estabelecido para o trabalho, observada a jornada } \\
\text { legal, sem atrasos e/ou saídas antecipadas }\end{array}$ \\
\hline Assiduidade & Comparecer continuamente ao trabalho, sem apresentar faltas \\
\hline Iniciativa & $\begin{array}{l}\text { Saber agir de forma pronta e eficaz perante as atribuições que lhe } \\
\text { forem conferidas; participar e buscar soluções previstas e não previstas; } \\
\text { apresentar sugestões de melhoria factiveis, consideradas as metas de } \\
\text { sua unidade de trabalho }\end{array}$ \\
\hline Flexibilidade & $\begin{array}{l}\text { Ser capaz de receber sugestões de melhoria no trabalho; respeitar a } \\
\text { opinião dos outros; adaptar-se a situações diferenciadas de trabalho; } \\
\text { rever comportamentos e atitudes que possam prejudicar o ambiente } \\
\text { de trabalho }\end{array}$ \\
\hline $\begin{array}{l}\text { Produtividade e } \\
\text { qualidade no trabalho }\end{array}$ & $\begin{array}{l}\text { Executar o trabalho segundo os padrões exigidos, observados o volume } \\
\text { de tarefas, os prazos e o grau de exatidão necessários à realização dos } \\
\text { objetivos da unidade }\end{array}$ \\
\hline Disciplina & $\begin{array}{l}\text { Acatar os preceitos, normas, legislação, deveres morais e bons } \\
\text { costumes, respeitar a hierarquia }\end{array}$ \\
\hline Ética pública & $\begin{array}{l}\text { Ter compromisso profissional, legal e moral para realizar suas } \\
\text { atribuições, agindo com a necessária discrição e sem discriminação }\end{array}$ \\
\hline $\begin{array}{l}\text { Cuidados com materiais, } \\
\text { equipamentos e } \\
\text { ambiente }\end{array}$ & $\begin{array}{l}\text { Zelar pelo patrimônio público, preservando e mantendo organizados } \\
\text { materiais, equipamentos e o ambiente onde se der o exercício das } \\
\text { atribuições funcionais; utilizar equipamento de segurança conforme } \\
\text { normas técnicas e/ ou legais, quando necessário ao desempenho de } \\
\text { suas atribuições e tarefas }\end{array}$ \\
\hline $\begin{array}{l}\text { Relacionamento } \\
\text { interpessoal }\end{array}$ & $\begin{array}{l}\text { Interagir com as pessoas e equipe de trabalho, administrando conflitos, } \\
\text { pautando suas atitudes na cooperação e respeito mútuo, necessários } \\
\text { para obter resultados positivos no trabalho }\end{array}$ \\
\hline
\end{tabular}

Fonte: Decreto municipal no 530/2010.

A Tabela 1 apresenta os 10 requisitos em que os servidores municipais de Curitiba são avaliados. A descrição dos fatores de avaliação presente no corpo do Decreto no 530/2010 é a mesma encontrada no instrumento de avaliação. 


\subsection{O Caso de Florianópolis/SC}

A avaliação de estágio probatório em Florianópolis tem uma periodicidade semestral. É realizada pela chefia imediata e dois servidores indicados por essa, juntamente com o servidor avaliado. Os servidores indicados devem ser efetivos e estáveis, assim como exercer suas funções no mesmo local de trabalho onde está lotado o servidor em estágio probatório. A avaliação realizada é convertida em conceitos, tornando-se estável o servidor que obtiver o conceito apto.

Há previsão de suspensão do estágio quando houver afastamentos superiores a 10 dias consecutivos ou 30 dias intercalados durante o período do estágio probatório. O servidor será exonerado se obtiver dois conceitos 'não atende', três conceitos 'atende parcial' ou dois conceitos 'atende parcial' e um 'não atende' em qualquer período das avaliações. Também poderá ser aberto processo de exoneração quando a gerência de perícia médica do município considerar o servidor em estágio probatório incapacitado definitivamente para o exercício do cargo para o qual prestou concurso.

Não há indicação expressa na legislação de vinculação do resultado da avaliação de estágio probatório com ações de capacitação e desenvolvimento profissional. O instrumento de avaliação utilizado é único para os diferentes cargos do município. O campo relativo aos requisitos de avaliação possui uma escala com três graduações para cada item, sendo posteriormente cada marcação multiplicada por um número de um a três de acordo com a coluna assinalada (1 para apto - atende aos requisitos; 2 para atende parcialmente aos requisitos; e 3 para não apto). Na Tabela 2, são apresentados os requisitos avaliados no município e a respectiva descrição constante no instrumento de avaliação. 
Tabela 2 | Requisitos de avaliação de estágio probatório de Florianópolis descritos no instrumento de avaliação

Descrição de requisitos de avaliação apresentada pelo instrumento de avaliação

Qualidade do que ou de quem é idôneo: quem tem capacidade para desempenhar determinada atividade ou ocupar certo cargo, ou de quem se pode supor honestidade. Aptidão, ser conveniente, adequado, próprio para desempenhar as atribuições do cargo, ética pública. Capacidade legal

Idoneidade e moral para realizar ações adequadas às exigências das tarefas de sua competência voltadas para as metas da unidade de trabalho. Sabe dos seus compromissos e demonstra discrição sobre assuntos com os quais trabalha. Pode-se confiar em relação à seriedade com a qual desenvolve as suas atribuições.

Obediência às regras, aos superiores, ao regulamento. Ordem, conduta que assegura o bem-estar do indivíduo ou o bom funcionamento de uma organização. Comportamento metódico, determinado, constância. Respeito às leis e normas, organização de tarefas, considerando o Disciplina cumprimento dos procedimentos estabelecidos e o respeito à hierarquia. Conduta que assegura o bem-estar do indivíduo ou o bom funcionamento da unidade de trabalho. Refere-se à organização das tarefas, considerando o cumprimento dos procedimentos estabelecidos, o respeito à hierarquia. Cumpre efetivamente as normas legais e regulamentares e as ordens disciplinares. Suas ações são executadas conforme o estabelecido.

Refere-se ao comparecimento contínuo, dentro do horário estabelecido Assiduidade para o trabalho com permanência produtiva do mesmo. Justifica ausências conforme as normas. (Em tempo hábil).

Qualidade ou condição de pontual, cumprimento de horário, compromisso Pontualidade com o horário combinado. Comparecimento contínuo, dentro do horário estabelecido para o trabalho

Profissional, legal e moral para realizar ações adequadas às exigências das tarefas de sua competência. Apresenta sugestões para melhoria do

Capacidade de iniciativa trabalho e/ou busca participar na solução de situações previstas ou não na sua área de trabalho. Busca capacitar-se profissionalmente, inclusive aproveitando os cursos promovidos pela Administração Pública Municipal. Possui a iniciativa de buscar informações e conhecimentos necessários para executá-las nos padrões técnicos pertinentes. 
Descrição de requisitos de avaliação apresentada pelo instrumento de avaliação

Característica ou condição do que é produtivo; capaz de produzir. Volume de trabalho executado, dentro dos padrões exigidos, em determinado espaço de tempo, aliado à qualidade e atenção na execução correta das tarefas. Refere-se ao cumprimento do volume de trabalho executado, Produtividade dentro dos padrões exigidos, em determinado espaço de tempo. Observa as prioridades e utiliza toda sua capacidade e recursos materiais disponíveis. Aplica métodos, técnicas e procedimentos adequados aos objetivos do trabalho. Empenha-se para melhorar a atividade a ser executada, contornando as dificuldades que Ihe são impostas no dia a dia. Cumpre os prazos estabelecidos.

Capacidade de ser efetivo; efetividade, eficácia, virtude ou característica de (alguém ou algo); ser competente, produtivo, de conseguir o melhor rendimento com o mínimo de erros e/ou dispêndios possível. Tem capacidade de adaptar-se a novos métodos e a atender solicitações de trabalho que lhe são próprias. Reage adequadamente acatando as orientações ou assimilando novos métodos/procedimentos de trabalho.

Efetividade Possui habilidade de trocar e discutir ideias e comunicar-se com a equipe de trabalho e com o público em geral, de forma clara, com argumentação precisa, apoiando-se no respeito mútuo. Mantém o relacionamento considerado adequado, respeitando os limites profissionais e pessoais. Zela pelo bom relacionamento no ambiente de trabalho, servindo como mediador e conciliador em situações entre colegas e/ou colegas e chefias.

Obrigatoriedade de responder pelas obrigações próprias ou dos outros; caráter ou estado do que é responsável: que ou aquele que responde pelos seus atos ou de outrem, que tem condições morais e ou materiais de assumir compromisso, que ou aquele que deve prestar contas perante certas autoridades. Assumir os resultados, positivos ou negativos, decorrentes dos Responsabilidade atos praticados pelo próprio servidor ou, parcialmente, pela sua equipe de colaboradores. Refere-se ao zelo e organização de materiais, equipamentos e ambiente de trabalho. Desempenha as atribuições do cargo, respeitando as diretrizes e princípios da administração pública municipal. Mantém os cuidados na manutenção preventiva dos equipamentos na sua rotina, otimizando o ambiente de trabalho.

Fonte: Decreto municipal no 16.550/2016 - Anexo.

A Tabela 2 apresenta os oito requisitos em que os servidores municipais de Florianópolis são avaliados. O corpo do Decreto no 16.550/2016 também apresenta uma descrição dos fatores de avaliação, mas de forma mais sintética que a feita no instrumento (conforme apresentado no anexo 1). Os fatores assiduidade e pontualidade, assim como produtividade e efetividade também são conceituados de forma conjunta no corpo do referido decreto. 
Verifica-se, assim, diferenças na descrição dos requisitos de avaliação presentes no corpo do decreto e no instrumento de avaliação, que constitui anexo da referida legislação. Além de mais detalhada, a descrição do instrumento de avaliação também se mostra mais abrangente que a do decreto em alguns fatores. Nesse sentido, pode-se citar o requisito efetividade. No corpo do decreto, o fator recebe uma descrição pontual, a qual agrega também à do requisito produtividade: "execução do volume de trabalho conforme os padrões exigidos, em determinado espaço de tempo, aliada à qualidade e atenção no cumprimento correto das tarefas". Já no instrumento, somente o fator efetividade abarca aspectos como "capacidade de adaptar-se a novos métodos e a atender solicitações de trabalho que lhe são próprias", "conseguir o melhor rendimento com o mínimo de erros e/ou dispêndios possível" e "zela pelo bom relacionamento no ambiente de trabalho, servindo como mediador e conciliador em situações entre colegas e/ou colegas e chefias".

Considerando que o instrumento de avaliação é o material mais acessível aos avaliadores e avaliados para obter informações sobre tal procedimento, pode-se esperar que a avaliação seja pautada na descrição de comportamentos feita nele e não no corpo do decreto específico. No entanto, a inclusão de elementos distintos num mesmo requisito dificulta a sua análise, uma vez que o servidor pode ter um desempenho distinto nos diferentes aspectos considerados pelo mesmo fator. Tal fato acaba por exigir do avaliador um posicionamento sobre que aspecto é considerado mais relevante no contexto da avaliação específica.

\subsection{O Caso de Porto Alegre/RS}

A avaliação de estágio probatório em Porto Alegre tem periodicidade quadrimestral. É realizada por dois servidores: o responsável pelo estágio probatório e a chefia imediata do servidor ou sua chefia mediata e imediata, juntamente com o servidor avaliado. Para adquirir estabilidade, o servidor deve obter média mínima de 70 pontos nas avaliações.

Há a previsão legal de suspensão do estágio probatório a partir de afastamentos superiores a 60 dias no período de cada avaliação. O procedimento de exoneração pode se dar ao final do estágio, caso o servidor obtenha uma média inferior a 70 pontos nas avaliações realizadas, ou no transcorrer do período, caso obtenha três avaliações consecutivas abaixo da pontuação mínima para o período (60 pontos para as três primeiras 
avaliações, 65 para as três seguintes e 70 nas três finais). 0 servidor também poderá ser exonerado caso apresente mais de 30 faltas consecutivas ou mais de 60 intercaladas no período de um ano, ou haja sentença transitada em julgado que indique perda de seu cargo. O decreto ainda prevê a exoneração caso o servidor fique mais de 4 anos com o estágio probatório suspenso, exceto casos específicos definidos na legislação³.

A legislação municipal prevê a realização de capacitações obrigatórias durante o estágio probatório, comprometendo as chefias a liberar o servidor para comparecer a elas, bem como penalizando o não comparecimento injustificado do servidor com descontos na pontuação da respectiva avaliação. O texto legal ainda estabelece que, em caso de baixa pontuação, discordância na avaliação ou a pedido, o servidor em estágio probatório receberá acompanhamento funcional. O técnico responsável pelo acompanhamento funcional poderá indicar capacitação, medidas gerenciais, administrativas ou técnicas, além de mudança de local de trabalho para favorecer o desenvolvimento funcional do ingressante. O servidor em estágio probatório é avaliado nos fatores apresentados na Tabela 3.

Tabela 3 | Requisitos de avaliação de estágio probatório de Porto Alegre

\begin{tabular}{|c|c|}
\hline Requisitos & Descrição \\
\hline Postura profissional & $\begin{array}{l}\text { Considere se o trabalho, atividades e/ou tarefas atribuídas foram } \\
\text { desempenhadas com profissionalismo. }\end{array}$ \\
\hline Relacionamento profissional & $\begin{array}{l}\text { Avalie o modo de relacionar-se profissionalmente no local de } \\
\text { trabalho. }\end{array}$ \\
\hline Responsabilidade & Considere o quanto assumiu os compromissos do seu trabalho. \\
\hline $\begin{array}{l}\text { Observância de normas e } \\
\text { procedimentos de serviço }\end{array}$ & $\begin{array}{l}\text { Considere se foram cumpridas as normas, procedimentos, } \\
\text { deveres, obrigações estatutárias e as combinações realizadas. }\end{array}$ \\
\hline Aproveitamento do trabalho & $\begin{array}{l}\text { Considere a distribuição do tempo entre as diversas tarefas } \\
\text { desenvolvidas, segundo a importância das mesmas. }\end{array}$ \\
\hline \multicolumn{2}{|c|}{$\begin{array}{l}{ }^{3} \text { Constituem exceção ao limite de quatro anos de suspensão de estágio probatório os afastamentos motivados por: a) } \\
\text { exercício de função ou cargo de governo ou administração por nomeação ou designação de Presidente da República, de } \\
\text { Governador de Estado, de Presidentes dos Poderes Legislativo e Judiciário ou de Prefeito; b) exercício de mandato eletivo } \\
\text { federal, estadual ou municipal; c) exercício de presidência de entidade representativa de todas as classes de cargos que } \\
\text { congregue, no mínimo, cinquenta por cento de funcionários do quadro de cargo de provimento efetivo; d) licença para } \\
\text { tratamento de saúde; e) acidente em serviço, agressão não provocada no exercício normal das atribuições e moléstias } \\
\text { profissionais; ou f) cedência em reciprocidade para outra entidade pública de servidor estagiário detentor de cargo de } \\
\text { provimento efetivo de Professor. }\end{array}$} \\
\hline
\end{tabular}




\begin{tabular}{ll} 
Requisitos & Descrição \\
$\begin{array}{l}\text { Utilização de recursos } \\
\text { materiais }\end{array}$ & Avalie como foram utilizados os recursos materiais disponíveis. \\
\hline $\begin{array}{l}\text { Disponibilidade e } \\
\text { participação na área de } \\
\text { trabalho }\end{array}$ & $\begin{array}{l}\text { Avalie o quanto o servidor-estagiário envolveu-se, contribuindo } \\
\text { para o desenvolvimento da sua área de trabalho. }\end{array}$ \\
\hline Conhecimento do trabalho & $\begin{array}{l}\text { Considere em que medida o servidor-estagiário conhece o } \\
\text { trabalho, atividades e/ou tarefas a ele atribuídas. }\end{array}$ \\
\hline Qualidade do trabalho & $\begin{array}{l}\text { Considere se o trabalho, atividades e/ou tarefas desenvolvidas } \\
\text { foram bem realizadas. }\end{array}$ \\
\hline Rendimento do trabalho & $\begin{array}{l}\text { Considere se o trabalho, atividades e/ou tarefas foram } \\
\text { desempenhadas com produtividade. }\end{array}$ \\
\hline Assiduidade & $\begin{array}{l}\text { Considere a frequência ao trabalho. } \\
\text { Pontualidade }\end{array}$ \\
\hline
\end{tabular}

Fonte: Decreto Municipal no 16.256/2009 - Anexo.

A Tabela 3 apresenta os 12 requisitos em que os servidores municipais de Porto Alegre são avaliados. Destes, assiduidade e pontualidade são os únicos fatores que não acrescentam pontos ao resultado da avaliação, gerando decréscimo à pontuação final quando ocorrem faltas e atrasos. Os demais requisitos são assinalados em uma escala com quatro graduações para cada item.

O corpo do decreto que regulamenta o estágio probatório apenas cita os fatores de avaliação sem apresentar sua descrição. Essa está presente somente no instrumento de avaliação. Verifica-se, assim, uma descrição bastante sintética dos requisitos avaliados, exigindo dos avaliadores a adequação dos fatores à realidade de cada cargo.

\section{Discussão de aspectos relevantes no estágio probatório das capitais da região sul do Brasil}

Nas seções seguintes são apresentadas semelhanças e diferenças no processo de estágio probatório das três capitais analisadas. A primeira abordará aspectos relativos aos critérios adotados para estabilidade, exoneração e suspensão do estágio probatório, 
definição de avaliadores e vinculação com ações de desenvolvimento. A segunda abordará os requisitos de avaliação utilizados nas três capitais.

\subsection{Procedimentos do estágio probatório}

A partir das legislações e instrumentos de avaliação analisados, verificaram-se semelhanças e particularidades quanto aos procedimentos relativos ao estágio probatório nas três capitais analisadas. Em relação às semelhanças, identificaram-se a segmentação da avaliação ao longo do estágio probatório e a obrigatoriedade de mais de um indivíduo na condição de avaliador em cada aferição de desempenho, sendo sempre um deles a chefia imediata. Nenhuma das capitais, contudo, previu uma qualificação mínima para o desempenho dessa função.

Todas as capitais têm previsão legal para a suspensão do estágio, embora utilizem quantidades de dias diferentes para considerar prejudicado o período analisado. Cada uma delas também avalia um número distinto de requisitos de avaliação e possui critérios próprios para a aquisição da estabilidade e exoneração dos servidores em estágio probatório. Divergências também foram identificadas quanto à vinculação da avaliação especial de desempenho a ações de desenvolvimento dos servidores. No Quadro 1 são apresentadas, de forma simplificada, tais semelhanças e particularidades relativas às três capitais analisadas.

Quadro 1 | Procedimentos na avaliação de estágio probatório nas capitais analisadas

\begin{tabular}{|c|c|c|c|}
\hline Elementos & Curitiba & Florianópolis & Porto Alegre \\
\hline $\begin{array}{l}\text { Critérios para } \\
\text { estabilidade }\end{array}$ & $\begin{array}{l}\text { - Obtenção de } \\
\text { conceito apto (75 } \\
\text { pontos) } \\
\text { - Aprovação em } \\
\text { curso de formação } \\
\text { profissional }\end{array}$ & $\begin{array}{l}\text { Obtenção de } \\
\text { conceito apto }\end{array}$ & $\begin{array}{l}\text { Obtenção de média final } \\
\text { igual ou superior a } 70 \text { pontos }\end{array}$ \\
\hline
\end{tabular}




\begin{tabular}{|c|c|c|c|}
\hline Elementos & Curitiba & Florianópolis & Porto Alegre \\
\hline $\begin{array}{l}\text { Critérios para } \\
\text { exoneração }\end{array}$ & $\begin{array}{l}\text {-Não obter pontuação } \\
\text { mínima para } \\
\text { estabilidade } \\
\text {-Infração disciplinar } \\
\text { - Faltas ou baixa } \\
\text { pontuação no curso de } \\
\text { formação profissional }\end{array}$ & $\begin{array}{l}\text { - dois Conceitos não } \\
\text { atende } \\
\text { - três Conceitos } \\
\text { atende parcial } \\
\text { - dois Conceitos } \\
\text { atende parcial e um } \\
\text { não atende } \\
\text { - Incapacidade } \\
\text { definitiva para o } \\
\text { exercício do cargo } \\
\text { verificada pela } \\
\text { perícia médica do } \\
\text { município }\end{array}$ & $\begin{array}{l}\text { - } 3 \text { Notas seguidas abaixo da } \\
\text { mínima } \\
\text { - Média geral abaixo de } 70 \\
\text { pontos } \\
\text { - Faltas (mais de } 30 \text { seguidas } \\
\text { ou } 60 \text { intercaladas) } \\
\text { - Sentença penal irrecorrível } \\
\text { que declare a perda do cargo } \\
\text { - mais de } 4 \text { Anos de } \\
\text { suspensão do estágio } \\
\text { probatório }\end{array}$ \\
\hline $\begin{array}{l}\text { Critérios para } \\
\text { suspensão }\end{array}$ & $\begin{array}{l}\text { Não explicita prazo } \\
\text { mínimo }\end{array}$ & $\begin{array}{l}\text { - Mais de } 10 \text { Dias } \\
\text { consecutivos } \\
\text { - Mais de } 30 \text { Dias } \\
\text { intercalados }\end{array}$ & Mais de 60 dias \\
\hline Avaliadores & $\begin{array}{l}\text { Três avaliadores } \\
\text { chefia imedita do } \\
\text { servidor e dois } \\
\text { servidores estáveis } 4\end{array}$ & $\begin{array}{l}\text { Três avaliadores } \\
\text { chefia imediata } \\
\text { e dois servidores } \\
\text { estáveis que atuam } \\
\text { no mesmo local de } \\
\text { trabalho do avaliado }\end{array}$ & $\begin{array}{l}\text { Dois avaliadores } \\
\text { chefe imediato e chefe } \\
\text { mediato ou chefe imediato } \\
\text { e responsável pelo estágio } \\
\text { probatório }\end{array}$ \\
\hline $\begin{array}{l}\text { Desenvolvimento } \\
\text { profissional }\end{array}$ & Capacitação & $\begin{array}{l}\text { Ausente na } \\
\text { legislação }\end{array}$ & $\begin{array}{l}\text { - Acompanhamento } \\
\text { funcional } \\
\text { - Capacitação }\end{array}$ \\
\hline
\end{tabular}

Fonte: elaboração própria.

A necessária participação do gestor direto na avaliação de estágio probatório nas três capitais mostra-se coerente com o funcionamento dos órgãos públicos uma vez que esse é o representante da organização para distribuir as atividades nas equipes de trabalho e acompanhar os serviços prestados à população. O gestor tem, assim, tanto a possibilidade de acompanhar o desempenho do servidor ao longo do período de avaliação quanto a própria responsabilidade de fazê-lo pelo papel que ocupa.

Por outro lado, o fato de a responsabilidade pela avaliação não estar restrita somente à análise do gestor mostra-se igualmente positiva. Considerando que o resultado 
da avaliação de estágio probatório pode representar a exoneração do servidor, haver mais de um indivíduo responsável por sua realização pode reduzir a ocorrência de problemas comuns a processos de avaliação, como o subjetivismo ${ }^{5}$ ou efeito halo ${ }^{6}$, ao congregar a percepção de mais de uma pessoa na avaliação final.

A adequada qualificação dos avaliadores para realização da avaliação, nesse sentido, mostra-se essencial para sua execução satisfatória. No entanto, identifica-se uma lacuna na legislação analisada nesse aspecto. Nenhuma das capitais exige qualquer qualificação prévia dos servidores para atuar como avaliadores, assim como não prevê capacitações específicas para eles, na legislação de estágio probatório, após assumirem tal função. Não se verificou também uma preocupação das instituições no sentido de estabelecer um padrão de avaliação similar no âmbito de cada ente, visando evitar exigências muito distintas quanto ao desempenho esperado por diferentes avaliadores. Este se mostra um ponto sensível do sistema de avaliação das capitais analisadas, uma vez que, na prática, servidores de um mesmo cargo e com nível de desempenho similar podem obter pontuações bastante distintas em função da exigência dos diferentes avaliadores.

Os três entes analisados apresentam previsão legal para a suspensão do estágio probatório quando o servidor tem afastamentos do trabalho por diferentes modalidades de licença, bem como quando assume funções distintas às do seu cargo de provimento efetivo. Nesse último caso, Curitiba e Florianópolis destacam a designação para função gratificada ou cargo em comissão e Porto Alegre para cargo em comissão. No entanto, Curitiba e Florianópolis preveem a possibilidade de continuidade do estágio probatório concomitante à ocupação de funções de confiança quando verificada a compatibilidade das atribuições do cargo efetivo com aquelas peculiares ao cargo comissionado ou função gratificada.

A previsão legal de suspensão do estágio probatório, quer por afastamentos legais, quer por desempenho de atividades diversas das atribuições do cargo de provimento efetivo, manifesta o respeito da legislação analisada à previsão constituicional de três anos de efetivo exercício do servidor para aquisição de estabilidade. Cada organização, no entanto, estabelece um limite para considerar prejudicado o período de avaliação nesse

\footnotetext{
${ }^{5}$ Subjetivismo constitui a tendência de atribuir ao avaliado características próprias do avaliador (ALVES, 2010).

${ }^{6} \mathrm{O}$ efeito halo refere-se à tendência de uma característica do avaliado influenciar os demais fatores avaliados (ALVES, 2010).
} 
sentido. Florianópolis estabelece mais de dez dias consecutivos ou trinta intercalados durante o período do estágio probatório. Porto Alegre prevê mais de sessenta dias em um perído de quatro meses. Curitiba, por sua vez, não especifica prazo mínimo para suspensão na legislação analisada.

Em relação aos requisitos para aquisição da estabilidade, duas capitais usam um conceito final de aptidão, e a outra, a média numérica de 70 pontos. Como critérios para exoneração, as capitais apontam o não alcance da pontuação mínima, ou de conceitos mínimos, para a aquisição da estabilidade, seja a exoneração durante o estágio probatório ou ao final do mesmo. Considerando que o estágio probatório visa verificar a capacidade do servidor em desempenhar as atribuições do cargo para o qual prestou concurso público (SOARES, 2012), nada mais natural do que esse ser analisado a partir de um parâmetro previamente definido pela legislação. No entanto, essa não é a única medida analisada para definir uma possível abertura de processo de exoneração do servidor em estágio probatório. Nesse sentido, Curitiba prevê, como motivadores para exoneração em sua legislação, a não aprovação ou a presença de faltas nos cursos de formação obrigatórios. Porto Alegre estabelece a suspensão do estágio por mais de quatro anos (exceto por afastamentos previstos na legislação) e Florianópolis, a incapacidade definitiva para o exercício do cargo verificada pela perícia médica do município.

As capitais também apontam fatores que não se mostram restritos a servidores em estágio probatório, como infração disciplinar em Curitiba e abandono de cargo, excesso de faltas ou sentença penal irrecorrível que declare expressamente a perda do cargo em Porto Alegre. Abandono de cargo, por exemplo, já está previsto no estatuto dos servidores de Porto Alegre, sendo assim automaticamente aplicável aos servidores em estágio probatório sem a necessidade de constar na legislação de estágio probatório. A redundância da capital em citá-lo novamente nessa legislação pode representar, assim, a expectativa desta em promover a exoneração do servidor da instituição de forma mais rápida a partir do decreto de estágio probatório.

Todos os instrumentos de avaliação analisados apresentam um campo de marcação, composto por uma escala de três ou quatro graduações, e outro de manifestação discursiva. Nesse último campo, Florianópolis e Porto Alegre apresentam apenas um espaço genérico para comentários dos avaliadores e do servidor avaliado. Curitiba, por outro 
lado, além de campo para observações, apresenta um espaço específico para indicação de procedimentos necessários para reduzir dificuldades apontadas durante a avaliação, o qual deve ser preenchido pelas chefias nos itens em que o servidor obtiver desempenho considerado regular ou fraco. Essse último campo citado mostra-se interessante ao ter seu preenchimento exigido quando o servidor apresenta um desempenho abaixo do esperado pela instituição, favorecendo assim a análise futura sobre o quanto as medidas para qualificação do desempenho foram, de fato, efetivas.

Nas três capitais, a avaliação de desempenho é dividida ao longo de cada ano, com periodicidades quadrimestral ou semestral, o que permite o acompanhamento sistemático do servidor em estágio por parte da organização. Embora o ideal fosse que todos os servidores recebessem retornos sobre o seu desempenho de forma periódica, a rotina das organizações, com frequência, não favorece esses momentos. Dessa forma, a segmentação da avaliação de estágio probatório em diferentes mensurações ao longo do ano acaba por oportunizar um espaço formal para dar feedback ao servidor sobre seu desempenho com uma regularidade definida. Caberá aos avaliadores e avaliados, no entanto, utilizar esse espaço da forma mais produtiva possível.

A articulação das avaliações de desempenho com ações de desenvolvimento profissional é referida na legislação de duas capitais. Curitiba tem previsão de encaminhamento de servidor com baixo desempenho para capacitação e Porto Alegre para acompanhamento funcional, além da previsão de cursos obrigatórios em ambos os casos. Nesse sentido, considera-se que o fato de a articulação entre as ações de avaliação e desenvolvimento estar regulamentada na legislação municipal favorece sua execução e continuidade ao não depender, em tese, da vontade do gestor municipal para sua implementação. Essa articulação também se mostra importante ao apontar um entendimento mais amplo sobre o estágio probatório, abrangendo, além da aferição de desempenho, o desenvolvimento funcional. Salienta-se como positiva ainda a indicação legal de que os gestores priorizem a liberação do servidor em estágio probatório para participação em cursos obrigatórios ou acompanhamento funcional oferecidos pelos órgãos, uma vez que atividades de desenvolvimento profissional não costumam ser priorizadas no dia a dia das organizações. 


\section{Requisitos de avaliação}

Cada município investigado apresenta um número distinto de itens considerados para a avaliação especial de desempenho: Curitiba, 10; Florianópolis, oito; e Porto Alegre, 12. Nenhum dos instrumentos de avaliação mostrou-se excessivamente longo em seu preenchimento e os fatores avaliados, de forma geral, constituem conceitos amplos e genéricos. Esse procedimento mostra-se condizente com um processo avaliativo que utiliza um único instrumento de avaliação para uma ampla variedade de cargos. Essa sistemática, no entanto, exige que os requisitos considerados sejam adaptados, pelos avaliadores, ao contexto de trabalho e às particularidades do cargo de cada servidor avaliado.

As capitais apresentam ainda nomenclatura distinta para abordar fatores similares. No Quadro 2 é apresentada uma breve descrição dos fatores avaliados pelas capitais, com o nome adotado por cada ente para representá-lo.

Quadro 2 | Quadro comparativo dos requisitos de avaliação de Curitiba, Florianópolis e Porto Alegre

\begin{tabular}{|c|c|c|c|}
\hline Requisitos avaliados & Curitiba & Florianópolis & Porto Alegre \\
\hline Número de requisitos & 10 & 8 & 12 \\
\hline $\begin{array}{l}\text { Comparecimento contínuo } \\
\text { ao trabalho, sem apresentar } \\
\text { faltas }\end{array}$ & Assiduidade & Assiduidade & Assiduidade \\
\hline $\begin{array}{l}\text { Cumprimento efetivo dos } \\
\text { horários de trabalho }\end{array}$ & Pontualidade & Pontualidade & Pontualidade \\
\hline $\begin{array}{l}\text { Cumprimento de normas, } \\
\text { legislações, deveres, respeito } \\
\text { à hierarquia, etc. }\end{array}$ & Disciplina & Disciplina & $\begin{array}{c}\text { Observância } \\
\text { de normas e } \\
\text { procedimentos de } \\
\text { serviço }\end{array}$ \\
\hline $\begin{array}{l}\text { Execução de determinado } \\
\text { volume de trabalho, } \\
\text { conforme os padrões } \\
\text { estabelecidos, em certo } \\
\text { espaço de tempo e } \\
\text { priorização de atividades } \\
\text { mais relevantes. }\end{array}$ & $\begin{array}{l}\text { Produtividade } \\
\text { e qualidade no } \\
\text { trabalho }\end{array}$ & Produtividade & $\begin{array}{l}\text { Aproveitamento } \\
\text { do trabalho e } \\
\text { rendimento do } \\
\text { trabalho }\end{array}$ \\
\hline
\end{tabular}




\begin{tabular}{|c|c|c|c|}
\hline Requisitos avaliados & Curitiba & Florianópolis & Porto Alegre \\
\hline $\begin{array}{l}\text { Execução do trabalho } \\
\text { segundo os padrões de } \\
\text { qualidade exigidos }\end{array}$ & $\begin{array}{l}\text { Produtividade } \\
\text { e qualidade no } \\
\text { trabalho }\end{array}$ & Produtividade & $\begin{array}{l}\text { Qualidade do } \\
\text { trabalho }\end{array}$ \\
\hline $\begin{array}{l}\text { Capacidade de assumir } \\
\text { os resultados decorrentes } \\
\text { dos atos praticados. } \\
\text { Responsabilidade por } \\
\text { compromissos assumidos. }\end{array}$ & Não avalia & Responsabilidade & Responsabilidade \\
\hline $\begin{array}{l}\text { Relacionamento interpessoal } \\
\text { estabelecido no ambiente de } \\
\text { trabalho }\end{array}$ & $\begin{array}{l}\text { Relacionamento } \\
\text { interpessoal }\end{array}$ & Efetividade & $\begin{array}{c}\text { Relacionamento } \\
\text { profissional }\end{array}$ \\
\hline $\begin{array}{l}\text { Aplicação de conhecimentos } \\
\text { técnicos e práticos } \\
\text { pertinentes ao cargo na } \\
\text { execução das atividades de } \\
\text { trabalho }\end{array}$ & $\begin{array}{c}\text { Conhecimento para } \\
\text { o trabalho }\end{array}$ & $\begin{array}{l}\text { Capacidade de } \\
\text { iniciativa }\end{array}$ & $\begin{array}{l}\text { Conhecimento do } \\
\text { trabalho }\end{array}$ \\
\hline $\begin{array}{l}\text { Agir de forma pronta e } \\
\text { eficaz perante as atribuições } \\
\text { que lhe forem conferidas; } \\
\text { participar e buscar soluções } \\
\text { previstas e não previstas; } \\
\text { apresentar sugestões de } \\
\text { melhoria factíveis }\end{array}$ & Iniciativa & $\begin{array}{l}\text { Capacidade de } \\
\text { iniciativa }\end{array}$ & $\begin{array}{l}\text { Disponibilidade e } \\
\text { participação na área } \\
\text { de trabalho }\end{array}$ \\
\hline $\begin{array}{l}\text { Zelar pelo patrimônio } \\
\text { público, preservando } \\
\text { materiais, equipamentos } \\
\text { e o ambiente onde se der } \\
\text { o exercício das atribuições } \\
\text { funcionais }\end{array}$ & $\begin{array}{l}\text { Cuidados com } \\
\text { materiais, } \\
\text { equipamentos e } \\
\text { ambiente }\end{array}$ & Responsabilidade & $\begin{array}{c}\text { Utilização de recursos } \\
\text { materiais }\end{array}$ \\
\hline $\begin{array}{l}\text { Capacidade de adaptação } \\
\text { a novos métodos de } \\
\text { trabalho e de atendimento } \\
\text { a situações diferenciadas } \\
\text { de trabalho. Capacidade de } \\
\text { receber sugestões e rever } \\
\text { comportamentos }\end{array}$ & Flexibilidade & Efetividade & Não avalia \\
\hline $\begin{array}{l}\text { Idoneidade, compromisso } \\
\text { profissional, legal e moral na } \\
\text { realizar de suas atribuições }\end{array}$ & Ética pública & Idoneidade & Postura profissional \\
\hline
\end{tabular}

Fonte: elaboração própria. 
Conforme ilustrado no quadro acima, apenas os requisitos que avaliam assiduidade e pontualidade recebem a mesma nomenclatura em todas as capitais analisadas. Em grande parte dos fatores, as capitais avaliam aspectos em comum com expressões similares. No entanto, também se verificam requisitos cujas descrições abrangem mais de um fator de avaliação de outro município, bem como requisitos distintos que parecem avaliar uma mesma temática.

Nesse sentido, os fatores aproveitamento do trabalho e rendimento do trabalho, avaliados por Porto Alegre, são mensurados por um único requisito nas demais capitais, o que acaba conferindo um peso maior a tal aspecto na capital gaúcha. Por outro lado, os fatores flexibilidade, produtividade e capacidade de iniciativa, avaliados por Florianópolis, englobam aspectos avaliados por mais de um requisito nas outras capitais, fazendo com que a cidade com menor número de fatores em seu instrumento de avaliação supere as demais quanto à abrangência de requisitos avaliados, em função da amplitude da descrição destes.

Embora os fatores avaliados, em todas as capitais analisadas, apresentem certa generalidade em sua descrição por serem utilizados para cargos distintos, a presença de um único requisito que abarque uma variedade muito grande de elementos não parece favorecer a realização da avaliação. Considera-se, nesse sentido, que tal ocorrência potencialize dúvidas quanto a que aspecto do fator deva possuir maior peso para determinar sua pontuação, o que pode favorecer divergências no entendimento do requisito por avaliadores distintos.

O relacionamento estabelecido no contexto do trabalho também ocupa espaço relevante na avaliação durante o estágio probatório. O serviço público é eminentemente um setor de serviços. O relacionamento estabelecido com o público atendido, bem como com pares, chefias e chefiados constitui, assim, um fator essencial para a boa prestação do serviço. As capitais também avaliam o cuidado e utilização de bens materiais. Considerando que os municípios constituem a esfera de governo com menor percentual de receitas públicas (SouzA, 1998), pode-se considerar que o uso dos recursos pode se mostrar um fator mais relevante nos municípios que em outras esferas.

Verifica-se, ainda, a influência dos modelos burocrático e gerencial na avaliação especial de desempenho. Observa-se, nesse sentido, a presença de fatores relativos ao 
seguimento de normas, tais como pontualidade, assiduidade e disciplina ou observância de normas e procedimentos, alinhados ao modelo burocrático e voltados ao atendimento rígido de procedimentos administrativos. Por outro lado, também se verifica o uso de diferentes nomenclaturas para avaliar fatores alinhados à administração gerencial, tais como produtividade e qualidade no trabalho, efetividade e rendimento do trabalho, mais voltados aos resultados a serem alcançados.

Considerando que os referidos modelos seguem princípios distintos, podemos pensar que o atendimento de requisitos influenciados por um dos modelos não necessariamente favorece o bom desempenho em um fator influenciado pelo outro. Nesse sentido, o servidor que apresente um desempenho exemplar quando avaliado em relação ao item disciplina ou observância de normas e procedimentos, pode ter, por esse mesmo comportamento, seu desempenho prejudicado em fatores como produtividade ou iniciativa. Caberá, assim, ao servidor avaliado administrar seu desempenho para atender da forma mais adequada possível os diferentes requisitos de avaliação.

Por fim, chama a atenção, nos instrumentos de avaliação, a presença de alguns fatores que apresentam maior dificuldade em serem analisados. Nesse aspecto, Porto Alegre se propõe a avaliar postura profissional com uma caracterização bastante genérica. Curitiba avalia ética pública, que abarcaria um compromisso profissional, legal e moral em sua atuação, bem como a adoção de uma postura discreta e não discriminatória. Florianópolis, por sua vez, avalia idoneidade, quesito que abrange tanto adequação ou propriedade para desempenhar as atribuições do cargo, quanto conhecimento e prática da ética pública. Os requisitos de avaliação citados envolvem conceitos de difícil descrição e delimitação, como moral e ética. Considera-se que a presença de itens com essas características prejudica a condução de uma avaliação com pretensões objetivas, bem como pode favorecer divergência de entendimento do escopo do fator por parte de avaliadores e avaliado, constituindo-se em um potencial fator de conflito na condução da avaliação. 


\section{Conclusões}

A Constituição Federal estabelece os parâmetros básicos para o estágio probatório a todos os entes federativos: três anos de efetivo exercício e obrigatoriedade da avaliação especial de desempenho por comissão constituída para esse fim. A partir desse ponto, o texto constitucional deixa um amplo espaço para cada ente federativo adequar esse processo a sua realidade e a suas necessidades.

Apesar dessa autonomia, não se verificaram diferenças muito marcantes no processo de estágio probatório das capitais analisadas. Embora possuam número diferente de fatores avaliados e utilizem, por vezes, nomenclaturas distintas, as capitais avaliam requisitos similares no desempenho de seus servidores. Nesse sentido, os entes parecem não fazer uso da autonomia que possuem para adaptar os referidos instrumentos às especificidades de sua realidade. Esse aspecto mostra-se visível, seja na comparação entre as capitais analisadas, seja na análise específica de cada organização, uma vez que todos utilizam o mesmo instrumento de avaliação para uma variedade significativa de cargos.

Em relação aos requisitos de avaliação, verifica-se como ponto crítico a elevada abrangência de determinados fatores. Ao considerar diversos aspectos do comportamento em um único fator, é exigido do avaliador um maior posicionamento quanto à relevância de cada elemento do desempenho no requisito, ampliando a dificuldade de sua mensuração e aumentando a probabilidade de divergências. Nesse sentido, considera-se que uma maior delimitação na descrição dos fatores de avaliação favoreceria a adoção de um padrão mais uniforme na avaliação dos diferentes servidores.

Observa-se ainda nos instrumentos de avaliação a presença de fatores alinhados tanto ao modelo de administração burocrático, como disciplina, assiduidade e pontualidade, quanto ao modelo gerencial, como produtividade e qualidade no trabalho, efetividade e iniciativa. Considerando que a reforma administrativa, implementada na década de 1990 no serviço público brasileiro, não realizou uma substituição total do modelo burocrático pelo gerencial, mas manteve elementos de ambos os modelos atuando paralelamente (AZEVEDO; LOREIRO, 2003), esse funcionamento se manifesta também na avaliação durante o estágio probatório. 
Considerando que, além de um processo de avaliação, o estágio probatório também se constitui em um período de adaptação do servidor à organização pública e de desenvolvimento funcional, mostra-se relevante que essa perspectiva esteja presente na legislação que o regulamenta. Duas das capitais analisadas propõem ações de desenvolvimento para os servidores em estágio probatório com baixo desempenho, sejam essas formais, como participação em cursos, sejam elas informais, como a realização de acompanhamento funcional.

Verifica-se, contudo, que esse ponto não é uma unanimidade mesmo em uma amostra pequena como a analisada para este estudo. Pode-se considerar plausível, assim, que situação similar à de Florianópolis se repita em outros entes da Federação. Entende-se, no entanto, que a não utilização do estágio probatório no desenvolvimento profissional de seus servidores reduza os benefícios que esse período pode oferecer ao serviço público.

Em relação à capacitação dos avaliadores, os resultados deste estudo são ainda mais preocupantes. Nenhuma das legislações analisadas exige uma qualificação mínima para a atuação do servidor enquanto avaliador no estágio probatório ou propõe a participação desse em capacitação específica. É necessário considerar que a mera ausência dessa capacitação na legislação não impede que os órgãos qualifiquem seus avaliadores. Contudo, entende-se que uma exigência nesse sentido, prevista em âmbito legal, favoreceria a sua manutenção, assim como auxiliaria o alcance de um nível mínimo de qualificação para os servidores que desenvolvem tal atividade.

Vale destacar que a atuação dos avaliadores é essencial para que as avaliações realizadas de fato reflitam o desempenho do servidor ingressante. A avaliação de desempenho não constitui um processo de simples execução e, no serviço público, ela assume uma complexidade particular, dada a sua estrutura de gestão própria, que possibilita a alternância de servidores em funções hierarquicamente superiores ao longo da vida funcional dos indivíduos.

Por fim, este estudo analisou somente a legislação referente ao estágio probatório das capitais investigadas. Sugere-se, assim, que novas pesquisas possam analisar a efetiva implementação das previsões legais no dia a dia das organizações. 


\section{Referências Bibliográficas}

AMORIM, T. N. G. F.; LUZ, L. C. S.; SILVA, L. B. Estágio probatório: contribuição efetiva para o servidor público? Administração Pública e Gestão Social - APGS, Viçosa, v. 3, n. 4, p. 273-295, out./dez. 2011.

Alves, F. T. Avaliação de desempenho na administração pública. Revista de Ciência Gerenciais, Valinhos, v. 14, n. 20, p. 87-104, 2010.

ALVES, H. G. A avaliação especial de desempenho para fins do estágio probatório face aos princípios constitucionais da legalidade e da eficiência: estudos de caso da avaliação dos servidores das Prefeituras Municipais de Itabira e Sabará, em Minas Gerais. 2014. 143 f. Dissertação (Mestrado em Direito), Universidade FUMEC, Faculdade de Ciências Humanas, Sociais e da Saúde, Belo Horizonte, 2014.

Azevedo, C. B.; Loureiro, M. R. Carreiras públicas em uma ordem democrática: entre os modelos burocrático e gerencial. Revista do Serviço Público, Brasília, v. 54, n. 1, jan./mar. 2003.

Bergue, S. T. Gestão de pessoas em organizações públicas. 2. ed. Caxias do Sul: Educs, 2007.

BRASIL. Lei no 1.711, de 28 de outubro de 1952. Dispõe sobre o Estatuto dos Funcionários Públicos Civis da União. Disponível em: <http://www.planalto.gov.br/ccivil_03/Leis/1950-1969/L1711. htm>. Acesso em: 18 set. 2019.

Constituição Federal (1988). Emenda Constitucional no 19, de 4 de junho de 1998.

Modifica o regime e dispõe sobre princípios e normas da Administração Pública, servidores e agentes políticos, controle de despesas e finanças públicas e custeio de atividades a cargo do Distrito Federal, e dá outras providências. Disponível em: <http://www.planalto.gov.br/ccivil_03/ Constituicao/Emendas/Emc/emc19.htm>. Acesso em: 18 set. 2019.

Lei no 8.112, de 11 de dezembro de 1990. Dispõe sobre o regime jurídico dos servidores públicos civis da União, das autarquias e das fundações públicas federais. Disponível em: <http:// www.planalto.gov.br/ccivil_03/LEIS/L8112cons.htm>. Acesso em: 18 set. 2019.

Plano Diretor da Reforma do Aparelho do Estado. Brasília: Ministério da Administração Federal e Reforma do Estado, 1995. Disponível em: <www.bresserpereira.org.br/Documents/ MARE/PlanoDiretor/planodiretor.pdf>. Acesso em: 18 set. 2019.

CURITIBA. Lei $n^{\circ} 10.815$, de 16 de outubro de 2003. Dispõe sobre o sistema de avaliação especial de desempenho para servidores em estágio probatório, revoga expressamente a lei no 9.723, de 30 de novembro de 1999, e o art. 4ㅇ da lei no 8.444, de 24 de maio de 1994, e dá outras providências. Disponível em: <http://leismunicipa.is/nbepf>. Acesso em: 18 set. 2019.

. Lei no 12.814, de 25 de junho de 2008. Altera, acresce e revoga dispositivos da lei no 10.815, de 16 de outubro de 2003, que "dispõe sobre o sistema de avaliação especial de desempenho para servidores em estágio probatório", revoga os arts. 79 e 80 do capítulo xi do título ii da lei no 1.656, de 21 de agosto de 1958, altera art. 1 으 e revoga art. 23 da lei no 11.768 , de 1 ㅇ de junho de 2006 . Disponível em: <http://leismunicipa.is/ngpef>. Acesso em: 18 set. 2019. 
Decreto no 530, de 6 de maio de 2010. Aprova o regulamento da avaliação especial de desempenho para servidores em estágio probatório de que trata a lei no 10.815/2003, com as alterações da lei no 12.814/2008. Disponível em: <http://leismunicipa.is/pcmdg>. Acesso em: 18 set. 2019.

Relação de cargos efetivos preenchidos. Disponível em: <http://multimidia. transparencia.curitiba.pr.gov.br/funcionarios/RELACAO_DE_CARGOS_EFETIVOS_PREENCHIDOS_ OUTUBRO_2018.pdf> Acesso em: 17 dez.2018.

FeitosA, C. M. C.; LIMA, A. V. Q. Avaliação de desempenho no setor público: fatores críticos e oportunidades de melhoria. In: ColóquIO INTERNACIONAL DE GESTÃo UNIVERSITÁRIA, 16., 2016, Arequipa, Peru. Anais... Arequipa: UFSC-CIGU, 2016.

FicagnA, A. V. O.; Silva, V.; ANTUnes, M. P.; Figueiro, W. C. Sistema de avaliação do estágio probatório: o caso da Prefeitura Municipal De Sarandi-RS. In: ENCONTRO DA ANPAD (ENANPAD), 38., 2014, Rio de Janeiro, Brasil. Anais... Rio de Janeiro: Anpad, 2014.

FlORIANÓPOLIS. Lei Complementar $n^{\circ} 63$, de 23 de setembro 2003. Dispõe sobre o estatuto dos servidores públicos do município de Florianópolis. Disponível em: <http://leismunicipa.is/poanl>. Acesso em: 18 set. 2019.

Decreto 16.550, de 11 de agosto de 2016. Regulamenta o processo de avaliação de desempenho de servidor nomeado para cargo efetivo no decorrer do estágio probatório e dá outras providências. Disponível em: <http://leismunicipa.is/rtseu>. Acesso em: 18 set. 2019.

Decreto 16.925, de 16 de dezembro de 2016. Altera o decreto no 16.550, de 2016, que regulamenta o processo de avaliação de desempenho de servidor nomeado para cargo efetivo no decorrer do estágio probatório e dá outras providências. Disponível em: <http://leismunicipa.is/ viojl>. Acesso em: 18 set. 2019.

Decreto 17.937, de 01 de setembro de 2017. Altera o art. 7ㅇ e o art. 14 do decreto $n$ 은 16.550, de 2016, que regulamenta o processo de avaliação de desempenho de servidor nomeado para cargo efetivo no decorrer do estágio probatório e dá outras providências. Disponível em: <http://leismunicipa.is/ivfsm>. Acesso em: 18 set. 2019.

. Relatório de funcionários. Disponível em: <http://adm.pmf.sc.gov.br/srh/funcionarios. pdf.php?lotacoes=Principal\%20Ativa\&regime=2\&tipo=Ativos\&detalhe=0\&in_output=l>. Acesso em: 17 dez. 2018.

GARCIA, M. E.; LIMA, M. I.; AssunçÃo, L. B. O desempenho no foco da gestão de recursos humanos: progressão e estágio probatório. Painel 36/140. In: CONGRESSO CONSAD DE GESTÃo PúBlıCA, 3., 2019, Brasília. Anais... Brasília: Consad, 2010.

GIL, A. C. Como elaborar projetos de pesquisa. 4. ed. São Paulo: Atlas, 2002.

LISBOA, R. L.; SANTIAGO, R. C.; JUNIOR,W. S. R. Trainee municipal: um caminho para profissionalização do quadro técnico das prefeituras. Painel 09/002. In: CONGRESSO CONSAD DE GeSTÃo PúBlıCA, 9., 2016, Brasília. Anais... Brasília: Consad, 2016. 
MODESTO, P. Estágio probatório: questões controversas. Revista Diálogo Jurídico, Salvador, n. 12, p. 1-27, mar. 2002.

Neto, A. S.; GomES, R. M. Reflexões sobre a avaliação de desempenho: uma breve análise do sistema tradicional e das novas propostas. Revista Eletrônica de Ciência Administrativa (RECADM), v. 1, n. 1, p. 1-24 maio. 2003.

NeVES, F. B. S.; BENITO, G. A.V. Refletindo sobre avaliação de desempenho do enfermeiro no contexto do Sistema Único de Saúde. Revista Brasileira de Enfermagem, Brasília, v. 57, n. 4, p. 459-63, 2004.

Porto Alegre. Lei Complementar 133, de 31 de dezembro de 1985. Estabelece o estatuto dos funcionários públicos do município de porto alegre. Disponível em: <http://leismunicipa.is/ gkubm>. Acesso em: 18 set. 2019.

Decreto 16.256, de 25 de março de 2009. Dispõe sobre o estágio probatório na administração centralizada, autarquias e fundação, e dá outras providências. Disponível em: < http://leismunicipa.is/cplua>. Acesso em: 18 set. 2019.

Decreto 16.972, de 22 de fevereiro de 2011. Inclui arts. 10 a e 16-a; inclui parágrafo único no art. 16, inclui § 5ㅇ no art. 18 e altera o "caput" do art. 19; todos do Decreto no 16.256, de 25 de março de 2009, que dispõe sobre o estágio probatório na administração centralizada, autarquias e fundação e dá outras providências; e revoga o Decreto no 16.807, de 23 de setembro de 2010. Disponível em: <http://leismunicipa.is/piguc>. Acesso em: 18 set. 2019.

Quadro síntese - servidores municipais. Disponível em: <http://lproweb.procempa.com.br/ pmpa/prefpoa/transparencia/usu_doc/quadro_sintese_-_201810.pdf> Acesso em: 17 dez. 2018.

REYNAUD, P. D. Avaliação de desempenho no estágio probatório de servidores técnicoadministrativos em educação: um estudo de caso na Universidade Federal de Santa Catarina. 2016. 215f. Dissertação (Mestrado em Administração), Universidade Federal de Santa Catarina, Centro Socioeconômico, Florianópolis, 2016.

SOARES, I. O. Efetividade do estágio probatório e o comprometimento com a instituição: um estudo com servidores de uma instituição de ensino superior. 2012. Dissertação (Mestrado em Administração). Faculdade de Ciências Empresariais - Fumec. Belo Horizonte, 2012.

SouzA, C. Intermediação de interesses regionais no Brasil: o impacto do federalismo e da descentralização. Dados, Rio de Janeiro, v. 41, n. 3, 1998. Disponível em <http://www.scielo.br/scielo. php?script=sci_arttext\&pid=S0011-52581998000300003\&lng=pt\&nrm=iso >. Acesso em: 27 set. 2019.

YIN, R. K. Estudo de caso: planejamento e métodos. 2. Ed. Bookman: Porto Alegre, 2001.

SUZUKI, J. A. N.; GABBI, L. V. B. Desafios da avaliação de desempenho no setor público: o caso da prefeitura municipal de São Paulo. Painel 13. In: Congresso CONSAD DE GeStÃo PúBLICA, 2., 2009. Anais... Brasília: Consad, 2009. 
Vanessa B. Nachtigall

(D) https://orcid.org/0000-0001-5749-0571

Especialista em Gestão Pública pela Universidade Estadual do Rio Grande do Sul (UERGS). Bacharel em

Psicologia pela Universidade Federal do Rio Grande do Sul (UFRGS), com MBA em Desenvolvimento Humano e Organizacional (IBGEN).

vanessa_nach@hotmail.com

\section{Paola Carmen Valenzuela Cánepa}

(iD) https://orcid.org/0000-0001-7330-6631

Universidade Estadual do Rio Grande do Sul - UERGS. Doutora e Mestre em Administração com ênfase em Sistemas de Informação na Tomada das Decisões pela Universidade Federal de Rio Grande do Sul (UFRGS). Bacharel Administração pela Universidad Del Pacífico (Lima - Peru). Professora adjunta na Universidade Estadual de Rio Grande do Sul - UERGS. Membro pesquisador no grupo de pesquisa Políticas, Gestão Pública e Desenvolvimento desta universidade.

通paola-canepa@uergs.edu.br

\section{Apêndice 1}

Tabela 4 | Requisitos de avaliação de estágio probatório de Florianópolis descritos no Decreto Municipal no 16.550/2016

\begin{tabular}{ll} 
Requisitos & Descrição no decreto \\
Idoneidade & $\begin{array}{l}\text { Aptidão; conveniência; adequação; propriedade para desempenhar as } \\
\text { atribuições do cargo; conhecimento e prática da ética pública; capacidade } \\
\text { profissional, legal e moral para executar ações correspondentes às } \\
\text { exigências das tarefas de sua competência. }\end{array}$ \\
\hline Disciplina & $\begin{array}{l}\text { Respeito às leis e normas, organização de tarefas, considerando o } \\
\text { cumprimento dos procedimentos estabelecidos e o respeito à hierarquia. }\end{array}$ \\
\hline Assiduidade & Comparecimento contínuo, dentro do horário estabelecido para otrabalho. \\
\hline Pontualidade & $\begin{array}{l}\text { Atitude de agir dentro dos limites de atuação no trabalho; domínio, de } \\
\text { forma atualizada, dos conhecimentos, técnicas e práticas. }\end{array}$ \\
\hline Capacidade de & $\begin{array}{l}\text { Execução do volume de trabalho conforme os padrões exigidos, em } \\
\text { iniciativa }\end{array}$ \\
\hline Produtividade & cumprimento correto das tarefas. \\
\hline Efetividade & $\begin{array}{l}\text { Capacidade de assumir os resultados positivos ou negativos decorrentes } \\
\text { dos atos praticados pelo próprio servidor ou, parcialmente, pela sua equipe } \\
\text { de colaboradores. }\end{array}$ \\
\hline Responsabilidade
\end{tabular}

Fonte: Decreto municipal no 16.550/2016. 